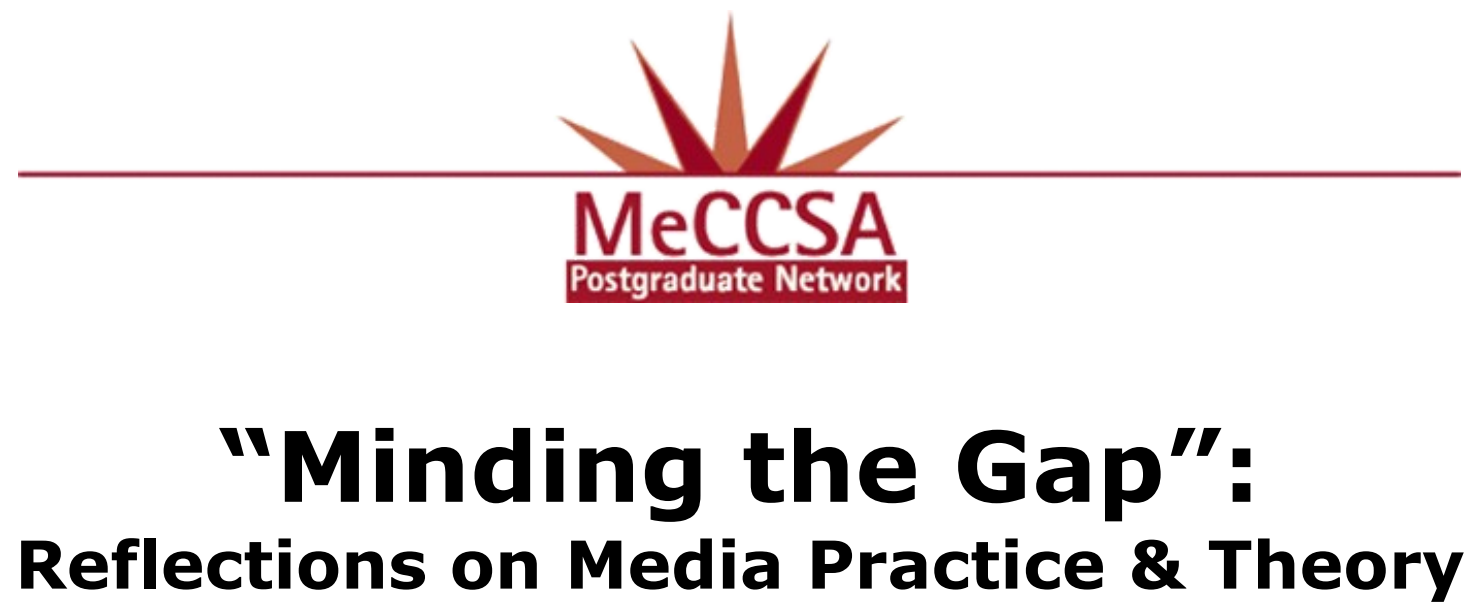

\author{
Postgraduate \& Early Career Researchers Training Day \\ Reuters Institute for the Study of Journalism, University of Oxford \\ Saturday $12^{\text {th }}$ May 2007 \\ Convenors: Paddy Coulter (Reuters Institute) \& Cathy Baldwin (ISCA) \\ Supported by: \\ MECCSA Postgraduate Network (ADM-HEA), \\ Reuters Institute \& ISCA, University of Oxford \& \\ Stanhope Centre for Communications Policy Research, London
}

MeCCSA Postgraduate Network \& Stanhope Centre do not have a centre view and do not aim to present one. The views expressed in this document are only those of its independent authors.
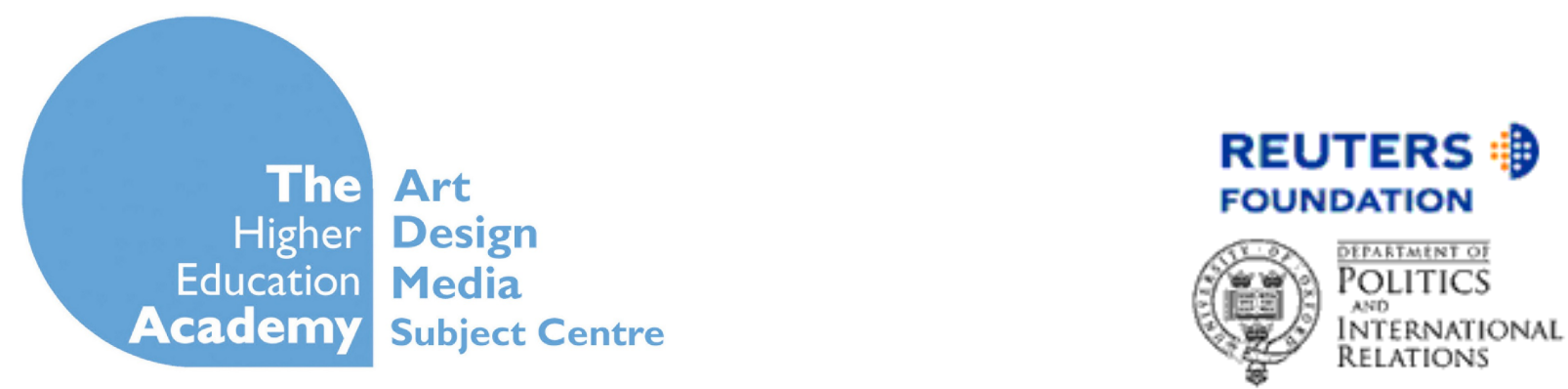


\section{Journalism and Political Democracy in Brazil}

By Dr Carolina Matos, Department of Media and Communications, Goldsmiths College, University of London, cop01com@gold.ac.uk

Many South American countries in the last two decades experienced significant political and social changes, embracing representative liberal democracy and the global market after having lived through relatively long dictatorship periods. After escaping from the tentacles of the military generals (1964-1985), which kept the country tied to an old economic model of state intervention and to a weak form of political institutionalisation with fragile freedom of expression, Brazil reduced the role of the state, diving into the waters of the market. At a first glance, the contemporary scenario seems to invite only optimism: the market permitted stronger governmental accountability and a means of safeguarding citizens from corruption. Political democracy was also consolidated, with full competitive and free elections held regularly. Certain groups of civil society players were included in the mainstream arena and a relative degree of press independence and freedom was achieved due to political democratisation and market expansion. The contemporary years nonetheless have been highly contradictory, with the market and the state and the various societal spheres being overwhelmed in tensions.

Media systems have thus been shaped by both market expansion and by the newly (re)gained political and civil freedoms which (re)emerged with liberal democracy. Due to the stabilisation of the country in the 90's, economic liberalism was to a certain extent inclusive because of the emergence of a wider consumerist market and society in the aftermath of the dictatorship. Market liberalism afforded the means for the incorporation of broader segments of civil society as legitimate members of the country's public sphere and as consumers. Political democratisation and market liberalism thus contributed on one side to improve political reporting in the press as well as having imposed restrictions on the proliferation of this same space of debate due to excessive commercialisation and political authoritarianism. Slowly, however, political reporting became more sophisticated and balanced, with public debate expanding amid the increase also of market pressures on news to lower quality standards. The commercial press in the last 18 years has thus experienced the tensions of attending to the public interest in response to political democratisation whilst maximising consumerism approaches to news. Thus, if on the one hand the democratic potential for the Brazilian media has grown in spite of the increase of media commercialisation, on the other hand there is still some way to go before a more representative democratic space is created in the mainstream media arena. 
Given the favouring of the professional and objective journalism style over partisanship in the decades of the 1980s and 1990s, one might ask how did journalists manage to contribute to advance democracy and promote social and political change if they relied mainly on instrumental tools (professionalism) rather than idealistic ones (militancy)? I argue that journalists did make contributions to the democratisation process through the use of multiple journalism identities. Different journalism models - militancy and professionalism - had their purposes, contributing to advance democracy in different periods of Brazilian contemporary history. The professional model is thus not flawed and is actually more relevant than ever in an era of increasing media concentration, excessive commercialisation and growth of political authoritarianism. One should thus avoid putting all the blame on journalism liberal values for the crisis of journalism world-wide. The decrease of interest in public affairs actually runs much deeper and is a result of a series of factors which include the decline of the Enlightenment project, the increase in relativism, growth of cynicism, individualism and consumerism.

Arguably, clashes between the market and the state have marked the contemporary years. The mid80s onwards saw the Brazilian media regain its political independence with the end of the dictatorship in 1985. The decade of the 90s saw also the definite consolidation of market-oriented news practices in newsrooms in the light of the emergence of the market as the main force of power in the post-dictatorship phase. The Brazilian press began to experience the tensions of attending to both citizenship and consumerism rationales, functioning as a restricted arena of debate of divided elites concerning the future direction that the country should take in the decade of the 90s. Hallin and Papathonassopoulos (2003: 3) have identified similarities between the Latin American media and Southern European systems. Among common characteristics are: 1) the low circulation of newspapers; 2) the tradition of advocacy reporting; 3 ) the instrumentalization (political use) of privately-owned media; 4) the politicisation of broadcasting and regulation and 5) the limited development of journalism autonomy. All these points can be applied to the Brazilian media, although in the last years professionalism and balance have grown and advocacy reporting is slowly falling, but has not disappeared altogether, as the coverage of the 2006 presidential elections has shown.

Similar to European newspapers, dailies in Brazil have had a strong political tradition, something which has not been abandoned altogether in the contemporary years. Veteran journalists have 
elected the more militant active journalism style that resisted the regime as being superior to the current contemporary commercial US model that has predominated in the Brazilian media. The alternative press during the dictatorship functioned as a sort of political and literary sphere (Kucinski, 1991; Waisbord, 2000) and had their main representatives in the alternative papers, O Pasquim and Opinião. These flourished during the dark years of the regime in Rio and São Paulo, with most of these dailies ceasing to exist after the end of the regime.

The state controlled the media widely during these years, a fact which undermines also the nostalgic stories of press resistance to the dictatorship, something which occurred more sporadically. Most of the mainstream media at that time preferred to engage in heavy official reporting than challenge military generals. The rule was cooperation between media firms and journalists with the government and not confrontation. Thus because of fears of censorship, the mainstream dailies such as Estado de São Paulo (ESP), Folha de São Paulo (FSP), O Globo and Jornal Brasil, the ones which I have examined in the case studies of my research, found difficulties in conducting critical political reporting. This slowly started to change from the mid-80s onwards, with the direct elections campaign of 1984 and the support given to it by the daily FSP for instance indicating that the media were slowly assuming a new relationship of critique of public authorities and the structures of the state.

With the collapse of the dictatorship, press exposés on corruption and abuses of power left the domain of alternative newspapers and were incorporated by the mainstream media as a major trend of contemporary journalism (Waisbord, 2000). The last years have thus seen the increase of the publication of stories on government corruption, with politicians having been made more accountable at the same time that market pressures and the pursuit of personal prestige by journalists has led to the rise of denuncismo journalism (journalism of denunciation) and the increase of cynicism. Opposing debates also emerged concerning the extent of the contribution of journalists to the democratisation process. Radicals critiques have tended to be nostalgic of a supposedly 'golden era' of journalism of critical debate that existed in the 70s in opposition to what they see today as being a highly market-driven environment. They tend to see the media in basically class terms and as being a mere reproducer of the values of the ideological apparatus, thus minimising the advancements that occurred in the journalism field in the last years and the contributions of journalists. Other journalists that I interviewed - and including myself, as I share 
this position - have tended to opt for a more 'realistic' position, seeing the complexity of the various forces at play (the market, the state, civil society and journalism) and the influence that each had on the media in the context of the advancements and resistances that occurred throughout the years.

Objectivity and professionalism during this period contributed for a fairer and a more complex portrayal of Brazilian politics and society. Similar to the emergence of the objectivity regime in the US during the 20s, professionalism in Brazil can be seen as a progressive ideology which undermines partisan media. Professionalism permitted the Brazilian media to attempt to be more inclusive and sophisticated. Contrary to the US and the UK, who have built their communication systems under a strong tradition of media independence, the Brazilian media has encountered difficulties in consolidating the Anglo-American commercial model. The development of the freedom of the press arrived late and is still being fortified. According to Schudson, after the First World War a more sophisticated understanding of objectivity arose grounded on beliefs that human beings cannot be objective, so they must strive to reach certain standard norms and practices. The rise is also linked to the dominance of scientific thought in Western civilizations, seen as vital for publishers who did not want to alienate readers and a necessity for journalists who wanted their work to be taken seriously. By the 60s, this value was an emblem of American journalism. Today the regime of objectivity has began to be wrongly criticised by radical critics in the West (for example, Schudson, 1978; Hackett and Zhao, 1998), who seem to take liberalism and free speech too much for granted.

Professionalism can be experienced in Brazil as being a double-edged sword. It can be empowering at times of pressure from market forces or from governmental bodies, affording them more editorial autonomy, but it can function also as a tool that can be used by media firms to control the behaviour of journalists (Hallin, 2000; Curran, 2000; Soloski, 1989). According to Soloski $(1989 ; 1991 ; 310)$, news professionalism controls journalists through the setting of rewards. Professionalism also means different things to different people (Curran, 1996: 101). The sensitivity of many journalists during the dictatorship period to the need to fight the regime was substituted in the redemocratisation period and further onwards for a professional pragmatism combined with an understanding of their role as journalists who can serve the public by engaging in investigative reporting, addressing social issues in the news pages and making use of professionalism. 
Journalists in Brazil since the 80s have thus been caught in an endless dilemma, paying lip service to the professional model identified with American journalism, with its insistence on detachment, while also struggling with other progressive readings of professionalism and with partisanship and democratic militancy. Furthermore, if on one hand professionalism gave new credibility and seriousness to the journalism profession in Brazil, on the other it put the journalist on a similar level to other liberal professionals.

Lichtenberg is one of the scholars who has revisited the objectivity debate and made a defense of it. For her objectivity is crucial if we aim to interpret and report a highly complex and changing world. It is also a way of permitting us to judge if one news story is 'better', or presents a more coherent and analytical picture of reality, than another. According to her (2000: 238), the main attacks on objectivity come from critics who say that the media have misrepresented their views, which implies that fairness can be achieved somehow. Arguably, it was precisely balance and fairness in political reporting that social groups and centre to centre-left-wing politicians who fought for democracy wanted from the Brazilian media. My research has pinpointed the differences between the 'better' stories which portrayed the Brazilian reality in all its complexities to the more partisan and ideological pieces in the in-depth investigation that I carried out on the political campaigns and presidential elections of the post-dictatorship phase (1984-2002). These included the 1984 direct elections campaign; the first presidential elections of 1989 followed by the 1992 impeachment; the elections of 1994, which elected Fernando Henrique Cardoso and occurred amid the launch of a stabilisation plan and the 2002 contest which elected the first left-wing government since the 1964 military coup.

During the contemporary phase multiple journalism identities coexisted in newsrooms. The tradition of opinionated journalism maintained its influence, with Brazilian journalism being also shaped by various international journalism trends and infotainment techniques. Liberal market democracy has thus paved the way for the expansion of confrontational reporting, with the growth of the watchdog function and critique of authority being seen as important democratic tools for societies that until recently were highly submissive towards government. Thus despite all of its faults, the media provide Brazilians today with more sophisticated, analytical and critical information than before, with less representation of politics in strictly partisan terms. Balance thus 
functioned to impede the publication of false news and prejudices that could serve to maintain privileges.

As I have also argued, the media to a certain extent also regressed, suffering from the (negative) impact of international journalism trends of infotainment and witnessing an expansion in media concentration due to excessive commercialization. These factors raise concerns again in relation to the limits that can be placed on the strengthening of the public debate arena which has been constructed with a lot of struggle. It stimulates debates on the fortification of a public media sector capable of serving as a counter-weight to the predominance of the commercial sector in the communication field as well as on the necessity to boast the creation of a complex communication system which can attend to the multiple interests of Brazilian society.

\section{Bibliography:}

Baker, C. E (2002) Media, Markets and Democracy, Cambridge: Cambridge University Press

Bardoel, J (1996) 'Beyond Journalism: A Profession Between Information Society and Civil Society’ in Tumber, Howard (ed.) News: A Reader, Oxford: Oxford University Press. 379-393

Brandford, S \& Kucinski, B (1995) Brazil - Carnival of the Oppressed, Nottingham: Russel Press

Calhoun, C (ed.) (1997) Habermas and the Public Sphere, Cambridge, Massachusetts and London: MIT Press. 1-50, 73-143, 359-402

Curran, J (2002) 'Media and Democracy: The Third Way' in Media and Power, London: Routledge. 217-248

Foucault, M (1972) The Archeology of Knowledge, London: Verso. 21-76, 79-88, 141-148, 166-177

Hackett, R.A \& Zhao, Y (eds.) (2005) Democratizing Global Media - One World, Many Struggles, Lanham, New York and Oxford: Rowman \& Little Field Publishers, Inc.1-37

Hallin, D. C \& Mancini, P (2004) Comparing Media Systems - Three Models of Media and Politics, Cambridge: Cambridge University Press.1-17, 21-86, 251-306

Herman, E.S \& Chomsky, N (2002) Manufacturing Consent - The Political Economy of the Mass Media, New York: Pantheon Books.1-37, 87-143

Lichtenberg, J (1991) 'In Defence of Objectivity Revisited' in Curran, J \&

Gurevitch, M (eds.) Mass Media and Society. Arnold: London. 238-255 